Approved for publication in David Thomas, ed., The Routledge Handbook of ChristianMuslim Relations (London: Routledge).

\title{
Early and medieval Muslim attitudes towards Christian doctrines Jon Hoover
}

\section{Introduction}

Muslims in the early and medieval periods of the Islamic tradition denied Christian beliefs about the Trinity, Jesus's divinity and sonship, the Incarnation and Jesus's death and atonement. One the earliest extant Muslim rejections of Christian doctrines, apart from the Qur'ān itself, is found in the Dome of the Rock in Jerusalem, which the Umayyad caliph 'Abd al-Malik commissioned in 692. The inscriptions on the Dome's arcade cite the qur'ānic affirmation of God's unity: 'Say! He is God, One, God, everlasting. He does not beget, and He is not begotten. There is no equal to him' (Q 112), and they include qur'ānic denials of Christian teachings: 'The Messiah, Jesus, Son of Mary was only a messenger of God and His word, which He cast into Mary, and a spirit from Him. So, believe in God and His messengers, and do not say "three". Desist! It is better for you. God is one deity only, and He is above having a son' (Q 4:171), 'It was not for God to take a son, glory be to Him. When He decrees a matter, He only says "Be!" and it is' (Q 19:34), and 'Praise be to God who did not take a son and has no partner in sovereignty' (Q 17:111) (trans. adapted from Donner 2010: 234-5). These inscriptions, along with the location of the Dome of the Rock within sight of the Church of the Holy Sepulchre, indicate that at least part of the reason for constructing the Dome was to distinguish Islam from Christianity and condemn its Trinitarian and Christological doctrines. It is sometimes suggested that qur'ānic verses such as those found in the Dome reject Christian heresies instead of Christian orthodoxy (e.g. Parrinder 1995: 133-7). However, Gerald Hawting (1999) has argued that these verses, and probably even the qur'ānic texts against idolatry and polytheism (shirk), were directed against orthodox Christianity. Either way, the Dome of the Rock clearly deploys the Qur'ān against the Nicene orthodoxy symbolised by the Church of the Holy Sepulchre. 
Denial of Christian teachings about the Trinity and Jesus' divinity came to be constitutive of Islamic orthodoxy. This does not usually appear in Muslim creeds themselves, but it does arise in commentaries on creeds and in treatises of Islamic theology. For example, al-Māturīdī (d. 944), in the section on prophethood in his theological work Kitāb al-tawhīd ('Book of unity'), denies the Incarnation and argues that Jesus was neither divine nor the Son of God. This is apparently to show that alternatives to Islamic prophetology are not viable (Thomas 2008: 79-117). In another example, the influential commentary of al-Taftazānī (d. 1390) on the creed of al-Nasafi (d. 1142) states that Christians disbelieve by upholding three eternals. Al-Taftazānī explains that Christians do not affirm three eternals openly. Rather, they affirm three hypostases, existence, knowledge and life, that is, Father, Son and Holy Spirit (Al-Taftazānī 1988: 37). This Arab Christian interpretation of the Trinitarian persons as existence, knowledge and life, or a similar set of three attributes, was well known among Muslims theologians from the ninth century onwards.

\section{Diversity of Muslim attitudes}

Early and medieval Muslim attitudes toward Christian doctrines ranged from repugnance and censure to accommodation. On the side of repugnance is an anonymous author in Aleppo during the Crusades, who writes, 'The most amazing thing in the world is that the Christians say that Jesus is divine, that $\mathrm{He}$ is God, and then say that the Jews seized him and crucified him. How then can a God who cannot protect himself protect others? ... Anyone who believes that his God came out of a woman's privates is quite mad; he should not be spoken to, and he has neither intelligence nor faith' (quoted in Hillenbrand 1999: 313). The reasoning behind such sentiments was developed in more sophisticated fashion in a clearly discernible polemical tradition. Mu'tazilis wrote a number of refutations of Christianity in the late eighth and early ninth centuries that are no longer extant. Early extant refutations include those of the Christian convert to Islam 'Alī al-Tabarī (d. c. 860), the Zaydī Shī̄i theologian al-Qāsim ibn Ibrāhīm (d. 860) and the philosopher al-Kindī (d. 864) (Thomas 1992: 31-7; Thomas 2002: 37-44). The subsequent three sections of this chapter will examine the arguments of three towering figures of the polemical tradition - 
Abū 'T̄sā al-Warrāq (fl. ninth century), 'Abd al-Jabbār (d. 1025) and Ibn Taymiyya (d. 1328) - against the Trinity, the deity of Christ and the Incarnation. A further section will examine attitudes toward Jesus' death on the cross and the atonement.

Some Muslim thinkers sought to accommodate Christian doctrines instead of rejecting them outright. This is found especially in Ibn al-'Arabī (d. 1240) and Sufi theorists of his ilk. Ibn al-'Arabī takes interest in triads. For example, the number three is the first of the odd numbers, and three divine names - God (Allāh), the Merciful (al-Raḥmān), and the Compassionate (al-Rahim) - are found in the invocation at the beginning of every qur'ānic sūra apart from the ninth. When discussing, 'They are unbelievers who say, "God is the third of three"' (Q 5:73), Ibn al-'Arabī notes that Christians are simply unbelievers (käfirūn) rather than polytheists (mushrikūn), and he affirms the Trinity as a divine unity (tawhīd) of composition and not outright polytheism. For lbn al-'Arabī there are two kinds of divine unity: the pure oneness of the Muslim tawhild and the composed oneness of the Christian Trinity, which includes three as the first odd number (Shahzad 2013: 116-18; cf. Lewisohn 2001: 137-42).

Muslims also responded to Christian doctrines by reinterpreting their biblical foundations to align with Islamic doctrine. A commentary on the Gospel of John called A/Radd al-jamīl ('The beautiful refutation') attributed to al-Ghazāli (d. 1111) gives metaphorical interpretations (ta'wil) to passages that Christians use to affirm Jesus' divinity. When for example Jesus said, 'I and the Father are one' (John 10:30), and the Jews threatened to stone him for blasphemy, Jesus realised that the Jews had misunderstood him to be speaking literally. So, he clarified by saying, 'Is it not written in your law, "I have said, 'You are gods?"' If He has called them "gods" because the word came to them ... then how much more for the one whom the Father has sanctified?' (John 10:34-6). According to Al-Radd al-jamil, Jesus' unity with the Father meant only that he had received a word from God, nothing more (Sweetman 1955: 262-309). Similar interpretations are found in the later commentary of Najm al-Dīn al-Ṭüfi (d. 1316) on the Gospels and parts of the Hebrew Bible. Al-Ṭüfí for instance accuses Christians of interpreting the Christological title 'Immanuel', that is, 'God with us' (Allāh ma'anä) literally to support the Incarnation (Matthew 1:23). Instead, al-Ṭüfi explains, the expression should 
be interpreted metaphorically to mean that in Christ '[God's] messenger, His decree, His command and His prohibition are with you' (Demiri 2013: 55, 138-9).

A further early and medieval Muslim approach to Christian doctrines is taxonomy. Polemical works often contain classifications of the three main Christian sects found within the classical Islamic world: the Melkites (Chalcedonians), the Jacobites (Syrian Orthodox), and the Nestorians (East Syrians). An example is the Fișal('Judgment') of Ibn Hazm (d. 1064) which, despite its sharp attack on Christianity, demonstrates substantial knowledge of the faith (Ljamai 2003: 52-60, 89-121). Taxonomies are found also in encyclopaedic works such as the Nihal wa -/-milal('Sects and divisions') of al-Shahrastānī (d. 1153). Al-Shahrastānī endeavours to provide a full account of the religious groupings of his time ranging across the various Muslim sects, the People of the Book and the philosophers. Under the People of the Book, he discusses Christians along with Jews, Zoroastrians and others. He details the basics of Christian teaching, and he outlines the doctrines of the three main Christian sects. While the presentation is largely descriptive, al-Shahrastānī does permit himself occasional criticisms, as when he notes that the Apostle Paul changed the Christian religion by mixing it with philosophy (Al-Sharastáni 1842: 171-9).

\section{Abū 'Tsā al-Warrāq on the Trinity and the Incarnation}

Abū 'Tsā al-Warrāq, a Mu'tazilī turned Shīī who lived in Baghdad in the mid-ninth century, also wrote what was apparently a survey of the major religious confessions of his time and then used this as the basis for his Al-Radd 'alā al-thalāth firaq min al-Nașārā ('The refutation of the three Christian sects'). Neither the survey nor the Radd is extant, but the Radd can be reconstructed because the Christian philosopher Yahyā ibn 'Adī (d. 974) copied most or all of it into his refutation of the work. Abū 'T̄sā's Raddis the most extensive critique of the Trinity and the Incarnation in the Islamic tradition and the longest refutation of Christianity prior to the fourteenth century. Despite his theological eccentricities on other counts, his Raddappears to have been the most definitive refutation of Christianity in its time, and it gained the attention of later Muslim scholars as well. The discussions of Christianity in the kalām theology manual Kitāb al-tamhīd ('Book of Introduction') of the 
Ash'arī al-Bāqillānī (1013) and in the massive Mughnī('Summa') of the Mu'tazili 'Abd alJabbār draw extensively on Abū 'T̄ā's Radd (Thomas 1992: 9-30, 41-50; Platti 2010: 413-15).

The Radd divides into a brief account of Christian doctrines and two long sections refuting the Trinity and the Incarnation respectively. The outline of Christian doctrines is reasonably accurate and considerably more nuanced than can be captured here. The basics are as follows. According to Abū 'Tsā, the three main sects - the Jacobites, the Nestorians and the Melkites - agree in their doctrine of the Trinity (tath/ith). They all speak of God as one substance (jawhar) and three hypostases (sg. uqnüm): Father, Son and Holy Spirit. The Father generates (wälid) the Son from eternity, and, following specifically eastern Christian doctrine, the Spirit pours forth (munbathiq) or emanates (fäiọ) eternally from the Father. Abū 'Tsā also writes of the Spirit pouring forth from both the Father and the Son. This is the doctrine of western Christianity, which he probably encountered in eastern Christian polemic against western Christians. Additionally, Abū 'T̄sā mentions common Christian analogies for the Trinity such as the generation of heat from fire and radiance from the sun.

With regard to the Incarnation, Abū T̄sā states that all three major Christian sects agree on the Uniting (ittihād). That is, the Son or Word united with a human being (Jacobites and Nestorians), or with the common substance found in all human individuals (Melkites), to bring Christ (al-Masihh) into existence. Beyond this, the Nestorian two-nature Christology, according to Abū 'T̄sā, clearly distinguishes the eternal substance, that is the Word, from the originated human substance born of Mary. Most of the Jacobites on the other hand claim that the two substances of the Word and the human from Mary united into the one nature of Christ (miaphysitism). The Melkites, according to Abū 'Tsā, maintain that Christ was two substances - the Word and the human - in one hypostasis. Abū 'Tsā then explores the implications of these three Christologies for Christ's crucifixion. $\mathrm{He}$ explains that Nestorian doctrine posits the crucifixion touching the human nature born of Mary but not the divine; the Melkites say that the crucifixion touches Christ entirely in both natures; and the Jacobites claim that it affected Christ, the one substance united out of 
two. Abū 'Tsā clarifies that the Jacobites say that the crucifixion could not have affected the divine nature if it had not been united with the human (Thomas 1992: 67-77).

In the subsequent sections of the Radd, Abū 'T̄sā al-Warrāq deconstructs these Christian teachings on entirely rational grounds. He makes no reference to either the Qur'ān or the Bible, and he focuses entirely on the lack of coherence and consistency in the doctrines. With respect to the Trinity, Abū 'Tsā refutes Christian proofs derived from the notion that three is the number of perfection, and he reduces various aspects of the divine hypostases to absurdity (Thomas 1992: 146-51, 154-79). A good many of his arguments are devoted to showing that one substance cannot be differentiated into three hypostases without entailing more than one eternal. He typically arrives at four eternals the substance and the three hypostases - but also at other quantities as well. For instance, Abū 'T̃sa argues that if the Father, Son and Holy Spirit are distinguished by the three properties of generation (Father), being generated (Son) and being poured forth (the Holy Spirit), that in fact makes six eternals (Thomas 1992: 76-131). As David Thomas has noted, Abū 'Tsā reads Christian doctrinal formulations as unequivocal statements about discreet and countable realities in God, which is not how Christians understood them (Thomas 1992: 63-5).

A further example of Abū 'Tsā's argumentation against the Trinity is his refutation of a proof that he traces to early Trinitarian theologians. Arab Christian theologians developed diverse iterations of this proof in an apologetic attempt to ground the Trinity in reason independently from scripture. According to the version recounted by Abū 'Tsā, the eternal substance is living rather than dead because it performs acts. This living substance also speaks because speaking is superior to not speaking. Now, the argument continues, the substance is not living by virtue of being a substance, nor is it speaking by virtue of being living. Otherwise, all substances would be living, and all living beings would speak, which is manifestly not the case. Rather, the one substance is living and speaking by virtue of the properties of life and speech. Additionally, being capable of generation is superior to its opposite, and so the eternal substance is also a progenitor. This makes God a living, speaking and generating substance, with life, speech and generation as His hypostases. To this argument Abū 'T̃sā responds that if the substance is not living by virtue 
of being a substance, then something else must be the cause of its life. Likewise with its speech; if the substance is not speaking by virtue of being living, then something else must be the cause of its speech. This however is false because God cannot be subject to external causes (Thomas 1992: 130-5).

Turning now to a sampling of arguments against the Incarnation, Abū 'Tsā wonders why it was the Word, and not the Father or the Spirit, that united with a human being. Among other things, this means that the Word engaged in an act that the Father and the Spirit did not engage in and furthermore implies that the other hypostases could also do things on their own. As Abū 'Tsā points out, this violates Christian teaching about the three hypostases being identical. Abū 'T̃sā also explains that Christian doctrine entails the unacceptable beliefs that Mary fell pregnant with and gave birth to the divine nature; that the divine nature grew up, suffered illness and so forth; and that the crucifixion of Christ either implicated the divine nature in death or, conversely, severed the divine nature from the human and destroyed their union, in which case the one crucified was no longer Christ. When focusing on the Melkites in particular, Abū 'Tsā draws out a whole range of absurdities that result from their doctrine that the Word united not with an individual human but with universal humanity. In a further series of arguments, Abū 'Tsā criticises the limitation of the Word and the divine nature to a particular physical and temporal body. Among other things, this reduces the size of the Word, and it renders the eternal perceptible to the senses (Thomas 2002: 96-181). It is readily apparent from Abū 'Tsā's argumentation that he presupposes that the divine cannot intersect ontologically with the human world of space and time.

\section{'Abd al-Jabbār on the Trinity and Christology}

The Mu'tazili theologian 'Abd al-Jabbār is known for two qualitatively different discussions of Christianity. The first is found within his Mughni, and it draws (among other sources) from Abū 'Tsā al-Warrāq without acknowledgement, as well as from a lost work by the Mut'azilī master Abū 'Alī al-Jubbāî̀ (d. 915-16). Much as in Abū 'T̄sā, 'Abd al-Jabbār's treatment in the Mughni begins with a brief description of Christian doctrines and then refutes the Trinity and the Incarnation in succession. It consists largely of arguments 
intended to show the irrationality into which Christianity fell by abandoning correct monotheistic doctrine (Thomas 2008: 205-377).

'Abd al-Jabbār's second discussion has been dubbed the Critique of Christian origins, and it is found within his Tathbit al-dalä'il al-nubuwwa ('Confirmation of the proofs of prophecy'), which he wrote in 995, five years after completing the Mughni. Unlike the Mughni, the Critique focuses mainly on the historical corruption of Christian scriptures, doctrines and practices. The middle part of the Critique narrates what went wrong. The early followers of Christ split into those who followed the original religion of Christ and those who colluded with the Romans and produced Gospels to replace the one Injil of Jesus. The Apostle Paul further corrupted the religion of Christ by introducing Roman elements such as permitting pork, forbidding marriage to more than one wife and not requiring circumcision and ritual washing. Later, the Roman Emperor Constantine imposed the Nicene Creed and killed those who opposed it ('Abd al-Jabbār 2010: 86111). Similar narratives are found elsewhere in the Islamic tradition and sometimes focus more directly on doctrinal corruption. For example, the Qur'ān commentator al-Tha'labī (d. 1035) traces the origins of the Nestorians, Jacobites and Melkites to three men named Nasțūr, Jacob and Mālik, respectively, whom the Apostle Paul taught the divinity of Jesus (Reynolds 2004: 164-5).

The earlier part of 'Abd al-Jabbār's Critique includes polemic against the Trinity and Jesus's divinity. Among other things, he accuses Christians of tritheism, idolatry (shirk), and anthropomorphism (tashbih), and he argues that the Prophet Muhammad was correct to report that Christians said 'Christ is God' $(Q 5: 17,72)$ and 'God is the third of three' (Q 5:73), even though Christians avoid such expressions ('Abd al-Jabbār 2010: 1-7, 30-32). 'Abd al-Jabbār also spotlights the qur'ānic passage in which God asks Jesus, 'Did you say to the people, "Take me and my mother as two gods besides God?"' (Q 5:116), in response to which Christians typically deny that they take Jesus' mother as a god. 'Abd al-Jabbār allows this denial to stand momentarily, and he explains that God's question to Jesus is only rhetorical: Jesus never called for anyone to worship him and his mother as gods! Nonetheless, 'Abd al-Jabbār goes on to explain that Christian veneration of Mary is tantamount to deifying her and that the Jacobite (but not the Nestorian) 
confession of Mary as the Mother of God explicitly affirms this. He further claims that Christians at the popular level believe that God had sexual relations with Mary: 'Know that the masses of the Christians believe that God chose Mary for himself and his son, that $\mathrm{He}$ selected her as a man chooses a woman and took her as a concubine because of His yearning for her' ('Abd al-Jabbār 2010: 80-5, quotation 85).

\section{Ibn Taymiyya on the Trinity and Christology}

Ibn Taymiyya, in Al-Jawāb al-șahịh li-man baddala dīn al-Masịh ('The correct answer to those who changed the religion of Christ'), draws his predecessors' polemic into a new synthesis to argue that Christianity fell foul of both reason and prophetic tradition much as Sufis, philosophers, kalām theologians and Shīiss had done among the Muslims. Ibn Taymiyya wrote Jawāb in 1316 or soon thereafter to refute the anonymous Letter from the people of Cyprus (Ebied and Thomas 2005: 54-147), which was in turn a revision of Paul of Antioch's Letter to a Muslim friend, written around 1200. The Cairene scholar Shihāb al-Dīn al-Qarāfi (d. 1285) wrote a refutation of Paul's treatise (see Sarrió Cucarella 2015), and the Damascene polymath Ibn Abī Țâlib al-Dimashqi wrote a refutation of the Cypriot Letter a few years after Ibn Taymiyya's (in Ebied and Thomas 2005: 150-497). These three refutations of Christian doctrines are among the most noteworthy in the Islamic tradition, and Ibn Taymiyya's is the longest and most sophisticated.

The Cypriot Letter is an apology for Christianity, and a major portion of the text is devoted to proving the Trinity and the Incarnation on the basis of reason and Biblical and qur'ānic texts. One of its key arguments for the Trinity is a rational proof similar to that already refuted by Abū 'T̃ā al-Warrāq. God the Creator is living lest He be dead and speaking lest he be ignorant. Thus, the living, speaking Creator is essence, speech and life, which are the Father, the Son and the Holy Spirit respectively. In Jawāblbn Taymiyya sidesteps this argument by noting that Christians derive their Trinitarian beliefs not from rational proofs but from texts such as, 'Baptize in the name of the Father and of the Son and of the Holy Spirit' (Matthew 28:19). He maintains that there is no particular reason that God should be limited to three hypostases or attributes and that Christians in fact claim that their doctrine lies beyond reason. Ibn Taymiyya counters that Trinitarian 
doctrine is not simply beyond reason but positively irrational, and, similar to 'Abd alJabbār, he asserts that the Christian teaching of the Father's generation of the Son reduces necessarily to God taking Mary as a spouse in the human way even if Christians resist that conclusion. It is a fundamental conviction for Ibn Taymiyya that reason and revelation agree and that the messengers of God would never communicate anything irrational. Thus, the irrationality of Trinitarian doctrine signals that Christians have necessarily altered the religion of Christ. If, Ibn Taymiyya argues, the revelation given to Jesus did mention the Father, Son and Holy Spirit, those names could not refer to the Trinity. Instead, the Father would refer to God, the Son to Christ whom God reared as His servant and the Spirit to the angel Gabriel or the divine revelation (Michel 1984: 255-79).

Ibn Taymiyya's rational polemic against the Incarnation in Jawāb is extensive, but two of his arguments will suffice to illustrate it. The first asks whether the Word that joined with the human nature of Christ was with God's essence. Now if the Word was with the divine essence, then the Father, Son and Holy Spirit altogether must have been joined in Christ, which Christians reject. Otherwise, the Word was only an attribute of God, not the Creator God Himself, and Christ had no role in creation, which the Christians also reject. To Ibn Taymiyya, such difficulties show the error of the Christian doctrine. In a second argument Ibn Taymiyya explains that the joining of the divine nature with the human nature or the indwelling of the divine therein implies that each nature has need of the other. However, God is the Creator of the human nature and can have no need of it. If God is said to dwell in humans, Ibn Taymiyya explains, it can only mean that they enjoy faith in God and knowledge of Him (Michel 1984: 286, 314-24).

Ibn Taymiyya complements such rational criticisms with charges of historical corruption of original Christianity. Christians changed the law of Christ and invented numerous doctrines and practices after the time of the early apostles, including the creed forged during the era of Constantine, and they innovated terms such as 'Trinity', 'hypostases' and 'union' and erroneously called God a 'substance' (Michel 1984: 303, 326, 343-5). Interestingly, Ibn Taymiyya does not resort to the imaginative story-telling of 'Abd al-Jabbār and others to account for this corruption. Instead, he copies extensively 
from the ecclesiastical history of Saîd ibn Bațīq (d. 940), letting a Christian witness narrate what is to him the evident distortion of the religion (Hoover 2012: 837-8).

\section{Crucifixion of Jesus and the Atonement}

The atonement and Jesus' death on the cross lie at the core of the Christian message. However, early and medieval Muslim writers gave them far less attention then the Trinity and the Incarnation, probably because, as Thomas has argued, refutation of the latter two doctrines better served polemicists and theologians in their primary objective of demonstrating the truth of Islamic monotheism (Thomas 2008: 5-14). Nonetheless, Muslim polemicists like al-Qāsim ibn Ibrāhīm were aware of the centrality of the cross in Christian teaching and devotion, and they were keen to deny that Jesus actually died and to object to the Christian portrayal of God's saving work (Beaumont 2008: 55-64).

The Muslim basis for rejecting Jesus's crucifixion and death is the qur'ānic verse, '[The Jews] did not kill him, and they did not crucify him. It only appeared to them so' ( $Q$ 4:157). This text denies only that the Jews crucified Jesus, and it is not clear that it excludes Jesus's death on the cross entirely. However, this became the dominant Muslim interpretation (Lawson 2009).

'Ali al-Tabarî's refutation of Christianity illustrates what Muslims found objectionable about the atonement. The Christian account of redemption common in the early centuries of the church and on into the early Islamic era took the fundamental human predicament to be bondage to Satan, which God then broke by tricking Satan into taking Jesus, the eternal Son, as a ransom. 'Alī al-Tabarī sees this as turning Christ's death into nothing more than a humiliating defeat at the hands of Satan. The whole drama amounts to praising Satan and mocking God, since Satan is in no way overcome. Such criticism led some Arab Christian theologians to reduce the role of Satan in their atonement accounts (Swanson 1995: 40-6). Nevertheless, Ibn Taymiyya saw need to provide a more philosophical critique of the same story several centuries later. According to his account, God certainly had the power to restrain Satan without resort to trickery, and the Christian account makes God out to be both powerless and unjust. If Satan had held humans justly for to their sins, then Christ should not have released them. Conversely, if Satan had 
imprisoned them unjustly, God should have released them long before Christ appeared. Ultimately, for Ibn Taymiyya there is no connection between the crucifixion of Christ and human salvation (Michel 1984: 223-4).

\section{Conclusion}

It is evident from this survey that early and medieval Muslims understood Christian doctrines not only to differ from their own but to challenge them as well. Christian teachings had to be refuted, historically relativized or at least domesticated in order to clarify and make intellectual space for the Islamic positions. It is perhaps not surprising that so much of this energy focused on the Trinity and the Incarnation because it was here that differences between Christians' and Muslims' visions of God became most apparent.

\section{References}

'Abd al-Jabbār (2010), Critique of Christian origins = Tathbìt dalāil al-nubüwah/'Abd alJabbār: A parallel English-Arabic text, ed. and trans. G.S. Reynolds and S.K. Samir, Provo, UT: Brigham Young University Press.

Al-Taftāzānī, Sa'd al-Dīn (1988), Sharh al-'aqāìd al-Nafasiyya, ed. Aḥmad Hịāzī alSaqqa, Cairo: Maktabat al-kulliyyāt al-azhariyya.

Beaumont, I.M. (2008), 'Debating the cross in early Christian-Dialogues with Muslims', in D.E. Singh, ed., Jesus and the cross: Reflections of Christians from Islamic contexts, Eugene, OR: Wipf and Stock, 55-64.

Demiri, L. (2013), Muslim exegesis of the Bible in medieval Cairo: Najm al-Dīn al-Tüfr's (d. 716/1316) commentary on the Christian scriptures: $A$ critical edition and annotated translation with an introduction, Leiden: Brill.

Donner, F.M. (2010), Muhammad and the believers: At the origins of /slam, Cambridge, MA: Harvard University Press.

Ebied, R.Y. and D. Thomas (2005), Muslim-Christian polemic during the Crusades: The letter from the people of Cyprus and Ibn Abì Tâlib Al-Dimashqīs response, Leiden: Brill. 
Hawting, G.R. (1999), The idea of idolatry and the emergence of Islam: From polemic to history, Cambridge: Cambridge University Press.

Hillenbrand, C. (1999), The Crusades: Islamic perspectives, Edinburgh: Edinburgh University Press.

Hoover, J. (2012), 'Ibn Taymiyya', in D. Thomas and A. Mallet, eds., Christian-Muslim relations: A bibliographical history, vol. 4 (1200-1350), Leiden: Brill, 824-78.

Lawson, T. (2009), The crucifixion and the Qur'an: $A$ study in the history of Muslim thought, Oxford: Oneworld.

Lewisohn, L. (2001), 'The esoteric Christianity of Islam: Interiorisation of Christian imagery in medieval Persian Sufi poetry', in L. Ridgeon, ed., Islamic interpretations of Christianity, Richmond, UK: Curzon Press, 127-56.

Ljamai, A. (2003), Ibn Hazm et la polémique islamo-chrétienne dans l'histoire de l'Islam, Leiden: Brill.

Michel, T.F. (1984), A Muslim theologian's response to Christianity: Ibn Taymiyya's A/Jawab Al-Sahih, Delmar, NY: Caravan Books.

Muḥammad al-Sharastáni (1842), Book of religious and philosophical sects, Kitāb al-milal wa al-nihal, ed. W. Cureton, London: Society for the Publication of Oriental Texts.

Parrinder, G. (1995), Jesus in the Qur'ān, London: Faber \& Faber, 1965 (repr. Oxford: Oneworld).

Platti, E. (2010), 'Yahyyā ibn 'Adī', in D. Thomas and A. Mallet, eds., Christian-Muslim relations: A bibliographical history, vol. 2 (900-1050), Leiden: Brill, 390-438.

Reynolds, G.S. (2004), A Muslim theologian in the sectarian milieu: 'Abd al-Jabbār and the Critique of Christian origins, Leiden: Brill.

Sarrió Cucarella, D.R. (2015), Muslim-Christian polemics across the Mediterranean: The splendid replies of Shihāb al-Dìn al-Qarāfi (d. 684/1285), Leiden: Brill.

Shahzad, Q. (2013), 'Accommodating Trinity: A brief note on Ibn 'Arabī's views', Journal of Ecumenical Studies 48, 114-20.

Swanson, M.N. (1995), Folly to the hunafä': The cross of Christ in Arabic Christian-Muslim controversy in the eighth and ninth centuries A.D., Cairo: n.p. 
Sweetman, J.W. (1955), Islam and Christian theology: A study of the interpretation of theological ideas in the two religions, Part Two, vol. 1, London: Lutterworth Press.

Thomas, D. (1992), Anti-Christian polemic in early Islam: Abū 'Tsā al-Warrāq's 'against the Trinity', Cambridge: Cambridge University Press.

Thomas, D. (2002), Early Muslim polemic against Christianity: Abū 'Tsā Al-Warrāq's 'against the Incarnation', Cambridge: Cambridge University Press.

Thomas, D. (2008), Christian doctrines in Islamic theology, Leiden: Brill.

\section{Further reading}

'Abd al-Jabbār (2010), Critique of Christian origins = Tathbit dalā'il al-nubūwah/'Abd alJabbār: A parallel English-Arabic text, ed. and trans. G.S. Reynolds and S.K. Samir, Provo, UT: Brigham Young University Press.

Michel, T.F. (1984), A Muslim theologian's response to Christianity: Ibn Taymiyya's A/Jawab Al-Sahih, Delmar, NY: Caravan Books.

Thomas, D. (1992), Anti-Christian polemic in early Islam: Abū 'Tsāa al-Warrāq's 'against the Trinity', Cambridge: Cambridge University Press.

Thomas, D. (2002), Early Muslim polemic against Christianity: Abū 'Tsā Al-Warrāq's 'against the Incarnation', Cambridge: Cambridge University Press. 